\title{
The Effects of Gender Diversity Through the Lens of the Body and Sexuality
}

Men in Greeting Work

Les effets de la mixité au prisme du corps et de la sexualité

\section{Sophie Louey and Gabrielle Schütz}

Translator. Juliette Rogers

\section{Q OpenEdition}

12 Journals

\section{Electronic version}

URL: http://journals.openedition.org/travailemploi/6846

DOI: $10.4000 /$ travailemploi.6846

ISSN: 1775-416X

Publisher

DARES - Ministère du Travail

\section{Printed version}

Date of publication: 30 December 2015

Number of pages: 109-132

ISSN: 0224-4365

\section{Electronic reference}

Sophie Louey and Gabrielle Schütz, «The Effects of Gender Diversity Through the Lens of the Body and Sexuality », Travail et Emploi [Online], Hors-série | 2015, Online since 30 December 2015, connection on 19 April 2019. URL : http://journals.openedition.org/travailemploi/6846; DOI : 10.4000/ travailemploi.6846 


\title{
The Effects of Gender Diversity Through the Lens of the Body and Sexuality Men in Greeting Work*
}

\author{
Sophie Louey ${ }^{* *}$, Gabrielle Schütz***
}

\begin{abstract}
Men holding so-called "women's" jobs have received little attention in academic studies of the effects of gender diversity on the sexual division of labour and careers. This article explores this issue based on studies of people in greeting work, emphasizing how the body and sexuality, which are particularly solicited by this activity, have an impact on gender relations. Two ethnographic studies in different greeting contexts (receptionists and special event hosting) show that gendered conceptions of the body participate in the establishment of a sexual division of tasks, which leads to greater freedom of action and less supervision for men in everyday work. "Flirting" at work has differential effects on greeters depending on their gender. It helps men preserve a traditional, heterosexual definition of virility, while allowing them to avoid the subordination and marginalisation resulting from their position in the division of labour and employment. At the same time, it keeps female greeters in occupational isolation. In conclusion, the study of greeters' careers is used to evaluate the possible existence of a "glass escalator" for men.
\end{abstract}

$\mathrm{R}$ esearch on gender diversity has shown its consequences to be mixed, simultaneously perpetuating unequal relations between the sexes and renewing how they are expressed (Baudoux, Zaidman, 1992; Cacouault-Bitaud, Charles, 2011). In the productive sphere in particular, it is manifest in a continuous remaking of segregated spaces, endlessly displacing the boundaries of the sexual division of labour (FORTINO,

\footnotetext{
* Translation: Juliette Rogers.

Article published in French in Travail et Emploi, ${ }^{\circ}$ 140, octobre-décembre 2014.

The authors would like to thank the members of the University Center for Research on Public Action and Policy (Centre universitaire de recherches administratives et politiques de Picardie - CURAPP) as well as Stéphanie Guyon, Isabelle Clair and Fabrice Guilbaud for discussing this text with them.

**Université de Picardie, CURAPP research center; sophie.louey@u-picardie.fr

*** Université de Versailles Saint-Quentin-en-Yvelines, Printemps research center (Professions, institutions, temporalities laboratory); gabrielle.schutz@uvsq.fr
} 
1999, 2002). The issues surrounding gender diversity in the workplace have been studied extensively from the perspective of women arriving in male bastions. Women's access to such occupations has not led to equality in tasks in everyday practice, nor to the equalisation of careers, women still hitting the "glass ceiling" as they climb the hierarchy (Laufer, 2005; Guillaume, Pochic, 2007; Buscatto, Marry, 2009). There have been far fewer studies, however, of "gender inversion" situations where men invest in "female" occupations (Williams, 1992; ANGELOFF, Arborio, 2002; Guichard-Claudic et al., 2008; Buscatto, Fusulier, 2013). Such research on men in "minority" situations is mainly focused on the sectors of health (KERGOAT, 1992; Charrier, 2004 and 2008; Douguet, Vilbrod, 2008; Picot, 2011), social work (PhilipPe, 2008; Bessin, 2008; Cresson, 2010; Bodin, 2011), and education (Galbraith, 1992; MurCier, 2008; Herman, 2007; Jaboin, 2008), or all three at once (Williams, 1992; Cross, Bagilhole, 2002). ${ }^{1}$ They have shown that advancements in gender diversity are the result of different processes for men and women, since there are differences in how they enter occupations where they are "minorities" as well as in the price they pay for this position and how their careers unfold (GUICHARD-CLAUDIC $e t$ $a l .$, 2008). These studies illustrate how the "ideology of complementarity" (HERMAN, 2007) leads to gender-based work assignments in the practice of the activity; they usually refer to the existence of a "glass escalator" (WILLIAMS, 1992), a metaphor referring to mechanisms benefitting men in "women's" occupations, leading them to be integrated with relative ease and enjoy rapid promotions.

Our study aims to contribute to the analysis of occupational situations where men are the exception in so-called "women's" occupations, based on service work in a sector that has received little attention in this literature: the for-profit services sector. ${ }^{2}$ Studying greeting jobs like receptionist and event host/ess (see box 1) creates a new approach to understanding how gender relations play out in such situations. Indeed, in representation jobs such as greeting, the body is extensively called on as a tool of seduction, therefore crystalising issues related to definitions of femininity as well as masculinity. The "appearance game" (HIDRI NEYs, 2013) underlies this kind of service work.

There are particular ways for men pursuing such "feminine" activities (which we know expose them to the suspicion of homosexuality; Cross, BAGILHOLE, 2002) to be able to negotiate a masculine identity. An analysis attentive to the "relational routine" (BROCHIER, 2011) of greeting work allows us to place more specific emphasis on the role of the body (and sexuality) in the elaboration of a sexual division of labour and men's and women's divergent career advancements in these situations. Studies of sexuality in organizations have generally pointed to the fact that it helps maintain the

\footnotetext{
1. In a much more isolated way, Pierre-Emmanuel SoRIGNET (2004) explored "gender inversion" in the "feminine" artistic field of dance.

2. With a few exceptions, such as Henri Peretz (1992) on luxury clothing sales, Kevin D. Henson and Jackie K. RoGERS (2001) on secretarial work through temporary employment agencies, Emmanuelle LADA (2008) on greeters for a public transportation company, and Sophie BERNARD (2011) on cashiers.
} 


\section{Box 1}

\section{Two Field Studies of People Working in Greeting Jobs}

Hosting is what Michelle PERroT (1987) calls a “women's occupation.” Generally consisting of part-time jobs, greeting and hosting work is often presented as a way for people to "reconcile" their working and domestic lives, and is a prime example of sexual division of labour that reserves tasks of assistance and image work for women. And indeed, women are the overwhelming majority in greeting work, which requires skills considered to be "feminine" (being welcoming, maternal, diplomatic) while imposing clothing and self-presentation styles that are also associated with a "feminine" imaginary (discretion, elegance, seduction).

Greeting and hosting work may take many forms. So-called event host/ess jobs are based on limited-term contracts and are nearly always worked through agencies that hire and dress their staff to greet and guide attendees at their clients' events (such as expositions for the general or a specialised public, business conventions, sporting events, soirées, or cocktail parties). The agencies offering this service hire on a permanent basis in order to build up a pool they can draw from according to the needs of each client; they usually hold as many recruiting sessions for men as for women, although more women apply and are called on for a far greater number of events. The vast majority of people in event hosting does this work alongside another activity, often as students, sometimes while looking for a first job after finishing school, and in some cases while pursing an artistic activity that does not allow them to earn a living (SCHÜTZ, 2011).

Being a receptionist is a line of work with a permanent employment contract, but usually part-time. It mainly consists of greeting and directing a company's visitors from a reception desk located in the lobby, which may also serve as telephone switchboard. Receptionists " may thus do what is called "physical" greeting, or may also answer the telephone in "mixed" hosting, or (more rarely) simply be operators, working from a dedicated office instead of the entry. We observed that these receptionists are less likely to be students than those working in event hosting, and are somewhat older; they usually have more working-class backgrounds and for nearly a third of them this is their main job -the rest are either looking for work in another field or are students, artists being more rare. The outsourcing of reception work has been gaining ground since the 1990s: estimates today put about two-thirds of companies of over 250 employees delegating their reception desk to an agency, while a fair number of small and medium enterprises (SME) also outsource reception, and all activity sectors, public and private, including government offices, take recourse to agencies (ScHÜTZ, 2011). A survey of receptionist service agencies leads us to estimate that 5 to $10 \%$ (at the most) of their receptionists are men. We do not have precise figures for non-outsourced receptionist jobs.

The results presented in this article come from two distinct studies. Gabrielle Schütz conducted research in agencies offering greeting and reception services. She observed 15 events, lasting from a few hours to three weeks, as an event hostess on a short-term employment contract. She then took internships in two agencies in the Paris area, a

1. The vast majority of whom are women; see below. 
mid-sized one named Angélique Hôtesses ${ }^{2}$ and a large one, Business Accueil, with branches nationwide. These internships lasted six and two months, respectively, and allowed her to observe the work of people managing reception services in these companies and to visit 15 reception desks in various client companies, spending one or two days at each and observing eighteen receptionists in working situations. Interviews with the staff of these two agencies and other reception and greeting services contractors (including Facil'Otess, Bienvenue and Réceptor) filled out the range of observations: people working in event hosting and reception $(n=37)$ and employees managing these services from the agencies' head offices $(n=29)$. Additionally, clients of both kinds of contractor $(n=14)$ were interviewed. A sociography of people in greeting work was drafted thanks to a database compiled from the personnel files at Angélique Hôtesses. The database consists of 279 women working as receptionists, and 246 women and 134 men working in event hosting. Lastly, several documentary resources, including professional publications, were analysed.

Sophie Louey conducted ethnography while part of the receptionist team at Entreprendre, a publicly subsidised business in northern France with about 60 employees and roughly 15 office-space tenants physically present in the same building. She was employed as a part-time receptionist on a student contract for three consecutive years, one of four receptionists who were all on long-term employment contracts: two "with benefits" (one woman working part-time, one man working full-time) and two on "student contracts" (a woman and a man working part-time). They worked in variable teams of two, which could be mixed, all male, or all female any given day. They were rarely all together in the same place, with the exception of Christmas and birthday parties. In addition to physical greeting and answering the telephone, this staff also had administrative tasks such as stuffing envelopes and putting postage on the company mail, managing employee reservations of company vehicles and meeting rooms, and so on. Each member of the reception team was interviewed, as were members of other departments, and long-term observations were made of interactions among receptionists, between receptionists and other company employees, and between receptionists and visitors to the company at the reception desk.

2. All proper names in this article have been changed.

subordination of women, especially emphasizing the role of harassment (MACKINNON, 1979; CROMER, LEMAIRE, 2007). Inversely, studying an occupation like greeting, where men are a "minority," enables a more precise approach to interconnections between sexuality in organizations, the division of labour between men and women, and effects on men's careers.

We will first turn to the question of the sexual division of labour between men and women in greeting work. Beyond highlighting differentiated tasks, analysis will show that mixing greeter genders creates more freedom for men in the practice of their work. Next, studying how greeters' bodies and sexualities are put into play in their work, we will focus on everyday interactions and more specifically how "flirting" affects greeters. Lastly, analysis will address the careers of all greeters and explore the relevance of the notion of "glass escalator" to greeting work. 


\section{Greeters at Work: Inequality in Integration}

If both men and women are hired for greeting jobs, it does not necessarily mean that they do the same activities. Whether or not they occupy the same position, women and men do not perform the same tasks and have generally internalised this division, which they help to justify and perpetuate.

For one thing, some greeting jobs are given exclusively to men. In event hosting, for example, women may be hired as drivers for bringing VIPs to receptions, but only men are hired as valet parking assistants for evening party guests. Traditionally, fashion show hosting is also reserved for men (we will come back to this), and women are never assigned to wear a sandwich board. Next, even when working together on the same job, men and women are not present in the same ways: they are often assigned to different positions, or the same positions, but at specific times of day. In reception work, for instance, a company closing especially late at night may prefer a man at the reception desk for the late shift, men being more readily taken for security guards and thus thought to be a better deterrent. When a company has multiple reception areas, men and women are not distributed at random. For example, according to one interviewee, Marc, age 36 and full-time receptionist for six years, ${ }^{3}$ the reception at the top floor of the major consulting firm where he works through an agency is always assigned to a woman: this reception desk is eminently ceremonial, its main task being to welcome upper management's visitors. In contrast, Marc's position has always been held by men: his job looks more like a superintendent's than a receptionist's, his work largely consisting of centralising and assigning office workers' requests for maintenance or cleaning staff intervention and arranging personal services for them (dry cleaning, photography, etc.). Men are also rarely assigned to positions whose sole purpose is representation. In companies very few men work at "pure" reception desks: they work at receptions with telephone switchboards, and more often at isolated switchboards. Likewise, in event hosting one rarely sees male hosts standing with their hands behind their backs, instructed to smile at everyone passing by, or placed in an "honor guard" along visitors' paths, as is often the fate of female hostesses. Instead of being sent to window-dressing positions, men are preferred for posts involving filtering and flowmanagement: they are found, for example, in reception facility parking lots, where they are supposed to point visitors to parking spaces or guests to their assigned seats.

But women and men may sometimes find themselves working together at the same reception area, an assignment in which they are theoretically interchangeable. Observations at Entreprendre showed that even in cases like this, differences emerge. More specifically, male and female greeters generally perform the same tasks when they work alone, but differences appear when they work together in pairs, first of all because the requests made of them are not the same. For example, when there is a task involving physical activity (such as moving a table), it is the man who will be asked for

3. To learn more about each interviewee, see the table in appendix; interview 7 January 2007. 
help, not the woman. And inversely, everyday "mindless" tasks that can be done behind the desk (stuffing envelopes, affixing postage) are assigned to female receptionists, regardless of the fact that contractually this kind of work is also for men. Although these requests tend to be directed specifically toward women or men, tasks nonetheless tend to be partially redistributed within the reception team. Male greeters will thus ask female greeters for help moving a table rather than asking higher-ranking male co-workers, and women turn to their male colleagues to share the secretarial work they have been given: within teams, the logic of hierarchy prevails over that of gender. Yet the distinctions between men's and women's tasks do not entirely vanish with these reception-area arrangements, so strong and incorporated are gendered representations, as illustrate the words of some employees at Entreprendre:

\begin{abstract}
"We do guy stuff; if we weren't here it'd be harder for [the women]. Sometimes we carry heavy things; we can also be really important when there are difficult visitors, because guys, you know, they've got more authority, you've got to admit it!"
\end{abstract}

(Christophe, age 30, full-time receptionist at Entreprendre for five years; interviewed 4 November 2011)

\begin{abstract}
"We girls have more things to stuff in envelopes, all that, while guys, it's more like taking packages up to the offices. [...] After that we do, like, the same work, we greet people, we answer the phone, so there's no difference, we all do the same thing. [...] Sometimes the guys are fed up with stuffing envelopes or preparing files, so we do it. Maybe we're more patient and methodical."
\end{abstract}

(Pauline, age 22, part-time receptionist at Entreprendre for two and a half years; interviewed 23 December 2011)

So gender diversity at the reception desk means neither "gender inversion" (GUICHARD-ClAUDIC et al., 2008) nor equality in the tasks. To the contrary, tasks considered "feminine" or "masculine" are reconstructed within it. They are marked by gender stereotypes attributing men with strength, initiative, and authority, as well as assigning them "technical" tasks or activities outside of the reception desk as such, and women are attributed with patience for minutia, representational work, passivity, interior work, and "decorative work." Although women spontaneously stress the equality of men and women's tasks, men (like people in charge of hiring them -see below) instead emphasize the "plusses" that their presence supposedly brings, as the preceding quotes have shown. ${ }^{5}$ These observations echo feminist studies like that of Danièle KERGOAT (2000, p. 36), which have shown that beyond the principle of the

4. Barbara GUTEK (1995) defines "decorative work" as jobs where being attractive (or more often, specifically beautiful) are an essential part of the job.

5. In addition to boasting, such quotes from men can also be understood as justification of the gender-boundary transgression that resulted in their holding positions generally reserved for women. Other men in "feminine" occupations have been found to say similar things (for example, see Cross, BAGILHOLE, 2002; CHARRIER, 2004; JABOIN, 2008; BEssin, 2008), which echoes how some women cite their "feminine" qualities as a "plus" in justifying their work in "men's" occupations, as found among female security guards (BAUVET, 2010) and managers (LAUFER, 1982). 
separation of tasks behind the gendered division of labour, the work associated with each sex is also assigned different social values and hierarchical positions.

Even if men are given certain physically demanding tasks (and do not hesitate to share them with their female colleagues), it seems that the sexual division of labour indeed gives them an advantage in the form of autonomy and initiative in their daily labours. Less constrained to representation and decorative work and managing somewhat to avoid the most repetitive secretarial tasks, male receptionists have more opportunities to escape the confinement of the reception desk, which is in consequence even more physically constraining for female receptionists. In this regard, differences between male and female receptionists play out what has already been observed in other work environments: for example, Michel GollaC and Serge VolKOFF (2002) have shown that male labourers have greater spatial mobility and less limited fields of action than female labourers, because they work less often on assembly lines.

\section{Greeting with Femininity and Virility: Uses of the Body and "Flirting"}

This unequal tethering of receptionists to the reception desk has consequences on how they use and control their bodies; it also has repercussions on their relations with visitors and other employees.

\section{The Gender of Disciplined Bodies}

In the words of agencies and their clients, reception is a "window" on the company, and as such imposes a number of corporeal prescriptions on staff, who ought to have "good presentation" and "proper attire" in terms of clothing and personal bearing (SCHÜTZ, 2006). These relatively generic requirements proliferate for female receptionists, however. In addition to listing everything, that staff should not do at the reception desk in the handbook, ${ }^{6}$ many service contractors go so far as to specify the height of high heels, and describe in great detail the kind of panty hose, jewelry, or makeup to be worn (or not), how their hair should be styled, or even the exact color of their lipstick and nail polish. ${ }^{7}$ There are no equivalent injunctions for male receptionists, who are simply asked to wear suits with matching polished shoes, have well-groomed

\footnotetext{
6. A few examples: being poorly seated, chewing gum, eating in front of visitors, slouching, leaning or sitting when reception is to be done standing.

7. These prescriptions are revealing of the place assigned to female receptionists by the hierarchy, but they say nothing of actual practices. Some receptionists knowingly "forget" to put their hair up or wear their work uniform, and others are sometimes deemed "vulgar" by their employer or the company where they work. This could happen, for instance, if they wear their own clothes or if their makeup is thought to be inappropriate, which leads to their being reprimanded and reminded in even greater detail of the kind of femininity that is expected of them.
} 
hands, a neat haircut, and be clean-shaven. The presentation of male receptionists is thus much less codified than women's, and is subject to much less scrutiny. ${ }^{8}$

Weighing particularly on women, these physical prescriptions correlate with tighter control of women's appearances. In event hosting, where bodily expectations are carried to the extreme, hostesses are sometimes subjected to inspection at the beginning of work, "lead hostesses" scrutinising their clothing, hair, and makeup. Posted outside less often than men and usually assigned to a specific position, hostesses are also more visible and consequently less likely to escape their supervisors' watchful eyes. They are thus regularly corrected on their bearing and attitude: "Stand up straight!," “Don't turn your back on people!," Smile!" Members of a cast production, they very often have to ask permission to go to the bathroom. Male hosts, who are freer in their movements and not working in narrow skirts and high heels limiting their mobility, are subjected to considerably less bodily control, ${ }^{9}$ as this event host for the agency Bienvenue remarked:

"Lead hostesses are a lot more strict with hostesses than lead hosts are with us, the hosts. With us it's more... we're more independent, actually, while hostesses, apparently -I don't know if it's just Bienvenue- it's really stricter, especially about hair... everything, actually. The lead hostesses on that -punctuality, hairstyles-are really strict. That is a difference, and you see it also in mixed-gender operations, where you find yourself with lead hostesses who manage guys and hostesses... But I've worked with other hostesses who've remarked to me, 'Shit, you guys, the bosses are a lot cooler with you guys!' Their own bosses, who are also our bosses, are much more easygoing with us than with them."

(Nicolas, age 25, event host for Bienvenue for four and a half years; interviewed 1 June 2004)

In reception desk work, the corporeal prescriptions weighing on reception staff are generally less restrictive. ${ }^{10}$ Bodily inspections nonetheless happen in much more diffuse forms that are still just as effective: it does not come from the imperative orders of lead hostesses orchestrating an event lasting a set period of time, but is driven more discreetly by a much larger group of people and acts through repetition over the long term. In contrast to contractors, Entreprendre does not provide uniforms to receptionists and clothing expectations are not specified. If male and female receptionists should be "well turned out," as specified in their contract, in practice women are more subjected to this obligation, which they learn to convert into an injunction

\footnotetext{
8. Men generally have less flexibility and room for creativity than women in how they can dress for work. This should be borne in mind in analysis of the more exacting codification of female greeters, as it makes it easier for women to deviate from the policed bourgeois gender representation expected of them, in contrast to their male equivalents (SCHÜTZ, 2006).

9. According to Colette Guillaumin (1992, p. 86), wearing skirts -which she describes as a "flounce around the genitals, attached at the waist like a lampshade"- makes them sexually available by offering up their bodies and forcing them to pay more attention in order to protect them.

10. Morphological criteria (for ideal height, body weight) are much less important in the selection of receptionists. Additionally, they do not always wear uniforms and their bodies, partially hidden behind the desks, are less exposed.
} 
to be "feminine." In everyday practice, women's presentation indeed attracts much more attention than men's, from their superiors as much as co-workers. They are thus regularly complimented or criticised for their wardrobes, when those of their male colleagues rarely draw comment. Consequently, as the two female receptionists on student contracts settled into Entreprendre, they gradually traded their sneakers and casual clothing for dresses, skirts, and high-heeled shoes. Their adjustment to their working environment thus took place through work on their bodies, leading them to create images of themselves that conformed to the norms of desirability driven by the heterosexual gaze.

Not only are female greeters' bodies the object of tighter control, but these women interiorise legitimacy more than their male counterparts. Reception staff at Entreprendre is not allowed to eat at the reception desk, but male receptionists do it anyway, while women invariably slip away to "snack." An interviewed event lead guest hostess, Amina, stressed that she thought that women took their representation responsibilities more seriously than men:

"The group ambiance is much lighter [when there are men] because generally male
hosts are there to play the... the... the clown. Well, they are kinda... [...] There is less
to criticise [for men], for one thing... And you know, there's no makeup. Sometimes
he hasn't shaved, but that, he knows it and he's generally aware of it... [while a
hostess is not always aware that she's poorly made-up or her hair's badly styled
according to the agency's criteria, as Amina had explained earlier in the interview].
Well, the suit, fine, you know, but fine... it's not the same, they don't take it as much
to heart either. They don't take it so much to heart, there's a difference there. That's
why I say it's much lighter. [...] After that, it's true that they are more difficult to
manage, for certain things, sometimes, you know, on the... on... on... everything
to do with... [...] If something stupid's going to happen, it's more likely to be them,
you know, I mean it's... No, but anyway that's it, since they take things less seriously,
more lightly, they can, I dunno, make... I worked a job as a hostess -not as lead
hostess- there's hosts who get wasted on the job."

(Amina, age 25, lead event hostess at Réceptor, where she has worked for six years; interviewed 25 November 2005)

Differences in how men and women exercise bodily self-control are not only related to a sort of "feminine docility" favouring apprenticeship and the respect of rules. More than a consequence of some generic passivity, female greeters' relative acceptance of the rules is more the result of a gendered internalisation of bodily control that is manifest, as Amina indicates, in the fact that women take comments about their appearances much more "to heart." In effect, this corresponds with art critic John Berger's observation: "Men look at women. Women watch themselves being looked at. This determines not only most relations between men and women but also the relation of women to themselves" (BERGER 1972, p. 47). So female greeters, as women, have internalised the pressure of the masculine gaze. Some may be critical of and irritated by the performance of gender expected of them -most often those 
for whom this work is secondary or temporary, especially students or young women looking for another job. But others think the bodily constraints imposed on them are legitimate, justified by the mission of hospitality -most often those for whom this is their main job, who have lower socio-economic capital. Regardless, most of them make an effort to conform as soon as they have a job. For men working greeter jobs, however, the need to look after their appearances and use them in their work puts them in a somewhat uncomfortable position. Their gender identity demands they not take this role too seriously, leading to a less-than-scrupulous respect for the rules and little concern about pointed remarks people might make. Without such an attitude they might be taken for vain men lacking virility, or even homosexuals. The goal of being "the prettiest," as some agencies suggest to their female employees, ${ }^{11}$ has no equivalent for male staff, being "the most handsome" certainly not being an issue for hegemononic masculinity (CONNELl, Messerschmidt, 2005). ${ }^{12}$

Physically disciplining themselves more than their male counterparts, women in greeting work perform what Colette GuILlaumin (1981, p. 25) calls a "bodily service." ${ }^{13}$ This use of women's bodies is, in the final analysis, related to the fact that their role is to play on the fantasy of the available woman and imply the possibility of contact outside of work. So in addition to the differentiated use of their bodies, their relations with the people they greet (as well as with other employees) set women in greeting work apart from men.

\section{"Flirting" at Reception, or Remaking an All-Male Sociability That Transcends Status}

Paying attention to flirting in greeting work reveals everyone's positions. Indeed, female greeters are subjected daily to the flirtation of visitors as well as the men working in the same place, a semi-ritualised flirtation in the sense that men do not usually intend to try to seduce but rather publicly affirm their masculine identity in its heterosexual dimension (ScHÜTZ, 2006). It is thus commonplace for men to address more or less explicitly sexual banter to female greeters, allowing men to affirm their virility, which in common thinking is most legitimately expressed through the proactive heterosexual solicitation of women (CONNELL, 1995). When confronted with this discourse, the women are usually silent, but they may also occasionally respond crudely

11. "Under no circumstances should your makeup be aggressive, but one should always have the impression that you took the greatest care to be the prettiest," specifies the services contractor Welcome in its "quality charter," which female employees must sign along with their employment contracts.

12. Beyond various incarnations of masculinity, the notion of "hegemonic masculinity," developed by Robert W. ConNell (1995, 2005), designates the significance of a norm, which, although only a limited number of men can assume it, constitutes an ideal reference -variable both historically and geographically-that hierarchically dominates other forms of masculinity.

13. Guillaumin (1981) uses this expression to designate what women owe men (as well as children and the infirm) without benefit of financial compensation. Henceforth we will consider that women's "bodily service" may be extended to the field of paid employment and representation work, to the extent that the greater bodily discipline to which these female greeters must subject themselves, despite being prescribed, is not recognised. 
and give themselves over to "linguistic deviance" (ZoLesIO, 2009), thus stepping out of their hospitality role and gender performance. ${ }^{14}$

Female greeters are stuck with the status of an object of (ostentatious) desire and suggestive jokes much more than other women working in the same place, even if they are just as young and pretty. The extent to which a woman is a flirtation target varies in relation to the degree of her exteriority. Consequently, among receptionists employed through agencies, those with a "permanent" position will usually be less solicited by male employees than those who are "passing through," serving as periodic impromptu fill-ins. Likewise, when receptionists are all internal employees (like at Entreprendre), those with a "permanent" position are less exposed to it than those with "student" contracts, whose time in the company is shorter and less certain. The female receptionist's position in the hierarchy -one of the lowest in most companies- and her salary level work in the same way, the intensity of their exposure to flirting going hand in hand with the degree of their subordination. Laurence, a woman who worked at reception three years at Entreprendre on a student contract while studying law in college and is now company representative, described it thusly:

"I was a young thing, I got hit on a lot. [...] That was part of the job. Today I'm not at reception; I'm the one who develops relations, today I've got a status that makes people respect me."

(Laurence, age 39, company representative at Entreprendre; interviewed 25 October 2011)

Men in greeting work are in a strikingly different situation. Not one case of flirtation targeting a man was observed directly during the study, but one man working in event hosting gave some examples in an interview:

"There's this guy, he totally... he came to see three pals. Me, I was just leaving right at that moment. He came to see them: 'Hey guys, you have girlfriends?' and all. Finally, of course, they said yes; they actually all said yes. And the guy earlier, one of the hosts, he'd asked him, 'What do you say if we make love?' and all, y'know... [...] And then there's a guy who gets his chest hair removed: 'You're too sexy' and all, y'know [laughing]! Yes, it happens... There's a guy, once, he really, he went like all out; he went to see the lead host; the guys wouldn't let up on him: 'Come on, we're going to party,' and all!"

(Steve, age 22, event host for Bienvenue for a year and a half; interviewed 17 March 2004)

All of these anecdotes are related to homosexual flirtation. One of them took place at the grand opening of an Yves-Saint-Laurent boutique where only men were hired; for the occasion their hair was styled like the designer's, and they were dressed in suits of his design worn bare-chested. Of all the special event jobs observed or recounted in

14. Such occasional forms of resistance take place in limited exchanges between greeters and are sometimes, though rarely, expressed in front of dumbfounded visitors. 
interviews, this was the one where the decorative dimension of male greeters was the most prominent. So when male greeters get hit on, it does not subvert the gendered order, since it happens in settings where they are considered aesthetic objects destined for the enjoyment of other men, not women. In fact one commonly given explanation for the custom for fashion show staff to be all men is the supposed preponderance of male homosexuals in this world, and not the presence of a predominantly female public. Although they are rarely hit on, observations at Entreprendre found that male greeters themselves often flirt, with female visitors and their female counterparts but not with higher-ranking female co-workers, once again confirming the connection between workplace flirtation and relationships of domination. ${ }^{15}$

The connections between workplace flirtation and the status of one's position therefore work in opposite ways for male and female greeters. Flirtation tends to confirm the subordinate status of women while allowing men to step out of the role.

When men hit on female greeters, they sometimes play back (as is expected of them), and they may seize the opportunity to affirm their feminine identity in its heterosexual dimension for themselves, and draw some satisfaction from it. Flirtatious relations leave them relatively vulnerable, however, as their occupational position and hospitable role-smiling, polite, and approachable-offer little latitude for turning away the unwelcome and spurning advances that require attentive assessment of their serious or playful character in order to respond appropriately. Getting hit on is an implicit part of the female greeters' job, but the fact that sexual activity is officially forbidden at the workplace also implies ensuring that the rules of propriety are respected. This responsibility falls mainly to women, as the parties most implicated in any debauchery that comes to pass purely as a result of their presence in the professional setting (SCOTT, 1990). These contradictory injunctions require female greeters to find what Pascale MOLINIER (2011), speaking of the sexual in geriatric care, called a "chimerical 'good distance'," without any instruction provided for doing so. Getting out of a situation of flirtation can prove difficult, when silence is taken as encouragement and a cold reply as failure to comply with occupational obligations; this is especially challenging for those most exposed to flirtation -the most subordinate- whose status makes any firm reaction especially tricky.

In contrast, flirting may provide an opportunity for male greeters to step out of their subordinate position, by remaking a masculine in-group sociability that surpasses hierarchical status thanks to a gender-based complicity with other male employees. Indeed observations at Entreprendre show that male employees not only hit on female receptionists, but also "outsiders", women working in other businesses renting office space in the same building who pass through without being part of the company. Male receptionists are complicit in the flirtation efforts of other male employees thanks to their strategic position; they may be asked to give them a call when the objects of their

15. These connections are also confirmed by the fact that female greeters usually have no difficulty getting out of unwanted flirting situations with their male counterparts, in contrast to the situation with visitors or other employees, with whom they are in a less assured position (see below). 
attention step out on a break, and sometimes they discuss their approach techniques with them after the fact. Over repeated interactions in the reception area, a reciprocal validation of their heterosexual flirting skills (and thus their virility) develops between male receptionists and employees, in a spirit of fun. Objects of workplace flirtation transactions, vectors of social connections more than active participants, women become pretexts and stakes for masculine competition. This makes it possible for male receptionists to see themselves as comparable to other male employees and provisionally escape their subordinate status, while female receptionists find themselves sidelined.

Although the gender-identity of male greeters may be threatened by their entering a "feminine" world, it seems that flirting at work -like the remaking of "feminine" and "masculine" tasks- to the contrary offers them a chance to affirm their virility, re-assert "the sexual order," and distance themselves from the repellant figure of the "fag" (CLAIR, 2012). Flirting also allows them to build other kinds of relationships with higher-ranking male employees, which begs the more general question of differences in male and female greeters' relationships to higher-ups and their respective career outlooks.

\section{Men's and Women's Careers in Greeting}

\section{Male Greeters Who Stand Out Above the Rest}

It is clear that male and female greeters are not in the same situation as far as their hierarchical superiors are concerned, first and foremost because they are not seen in the same way. Indeed, there is a widespread idea among agencies and at Entreprendre that mixed-gender greeting teams are preferable because they create "healthier" atmospheres. Gender diversity is at very least seen as producing a nicer ambiance, and may also be associated with the supposed discipline that men would bring to a feminine world many imagine prone to argument and rivalry. As Sabine ForTino (1999, p. 376) has indicated, in working environments associated with women, men are thought to be "agent[s] and factor[s] of social regulation," and male greeters are no exception to the rule:

"We regularly hire men. [...] And plus, a male greeter, he can also get the team to relax [...] when the female greeters don't get along or are in competition -that can be a plus."

(Marie, age 29, management assistant in charge of hiring greeters at Entreprendre for eight years; interviewed 24 October 2011)

"I much prefer working with men than with women. They are much easier to manage... [...] The girls will immediately look at each other, you know, really in a spirit of rivalry, I noticed..."

(Loretta, age 22, lead hostess at Réceptor for a year; interviewed 8 November 2005) 
Although allusions to rivalries between female greeters clearly revive deeply rooted stereotypes of women, they may also be interpreted as an echo of the contrasting discourse describing the levity that purportedly characterises male greeters not prisoner to a restrictive gender performance (see above). Additionally, in companies contracting receptionist services through an agency, female receptionists are reputedly less reliable, said to be more likely to be absent from work, despite the fact that the very low proportion of male receptionists makes any generalisation of the kind quite unreliable:

"And then, it's still a largely female population, so... Also, it's plain as day, there're far fewer problems with male receptionists. Girls are a lot more sensitive, really, so little troubles over love, this, that, health, they don't come to work... And that happens rather often. And it's really linked to the fact that it's totally a woman's occupation." (Samantha, age 32, in charge of receptionists at Angélique Hôtesses for four years; interviewed 16 November 2005)

Finally, workplace disorder and inefficiency arising from the presence of a female greeter who is the object of male desire and female jealousy are also a topic in the sector. For example, magazines like Arseg Info, a professional publication for facilities managers (who are reception service agencies' main contacts in client companies), describes the ideal receptionist as "young, but not too beautiful, so as not to cause traffic jams at the office," and proceeds to provide a testimonial from an agency affirming that beauty may be a "source of trouble" for a receptionist, using the example of a "truly gorgeous" young woman who aroused jealousy in all the female employees of the client company. ${ }^{16}$

Female and male greeters are also understood through a gendered template that psychologises their supposed qualities. As a result, they do not receive equal attention, either from management or the other employees they frequent daily. Among event hosts and hostesses, for example, where hiring is long-term and there are large numbers of workers, men (a minority) are often more rapidly identified and individualised than women. Observation of the (female) management at Angélique Hôtesses also showed that they generally find these hosts "delicious" and may develop bantering relationships with them, or even feign seduction. Interviews at other agencies confirm this attitude:

"I'm really happy to have a male receptionist. Plus, he's... [stage-sigh of contentment] he's a delicious boy who's very... present, so, very ... very polite, very courteous, very gallant, very ... oh, he's a love! [laughs]"

(Ariane, age 26, in charge of receptionists at Facil'Otess for seven years, interviewed 19 September 2005)

The presence of men at Entreprendre's reception desk does not pass without notice either, and draws other employees' attention much more than women's presence. It seems to be understood that a receptionist position can only be transitional for men, and male receptionists are frequently questioned about their prospects for professional advancement, practically being forced to justify their presence in the position. 
All the conditions seem to be in place for men to enjoy ascendant careers in greeting, or even move up and out: tasks letting them physically escape the desk, flirting conditions allowing them to periodically step out of their role, some privileged relationships with management and other employees who are often quick to spot their potential beyond greeting work. What is the reality?

\section{Do Male Greeters Have a "Glass Escalator”?}

Probing the existence of a "glass escalator" for male greeters demands a nuanced analysis that distinguishes between special event and reception desk greeting work, regardless of whether the work is done through an agency or not.

We observed that, in some agencies providing event hosting, men are more often assigned to jobs considered more prestigious, such as fashion shows, concerts, theatre, and openings. And inversely, men are less in demand for business conventions, medical conferences, and booths at professional expos, which employ a considerable number of women, sometimes at a lower hourly wage. In this regard, the distinction between men and women in greeting work is relatively continuous with the domestic service tradition; indeed, Geneviève FrAISSE (1979) makes a distinction between "ceremonial domesticity," masculine, associated with a certain social prestige for those holding it and a luxury destined to demonstrate the fortune of those using it, from "domestic service," feminine and socially devalued. Nonetheless, all agencies have considerably more demand for event jobs calling for women than for men, and these events also tend to last longer. If it is difficult, but possible, for women to live exclusively from earnings as event hostesses, ${ }^{17}$ it is unthinkable for men.

Comparison of the profiles of men and women working in event hosting was made possible by statistical analysis conducted during research in agencies providing greeting services (see Tables 1 and 2). It reveals further differences that make the glass escalator metaphor seem unsuitable for hosting. For one thing, although most hostesses are under age 24, their male counterparts are often over 25 . And despite the fact that women in event hosting have higher educational qualifications than the men, one can nonetheless make the following observation: while they hold the same proportion of higher degrees as the ensemble of women of their generation, the percentage of men with degrees is above their generational average, which might lead one to think that they are even less likely than their female colleagues to have a job considered unskilled. Coming to greeting work at an older age, men also seem to end up there more by default. ${ }^{18}$ It is less common for men to be students, and even fewer men imagine a career in greeting ( $0 \%$ as compared to $3 \%$ of women). More men look for work in another sector, ${ }^{19}$ and

17. Event hosting is the primary activity of an estimated 5 to $10 \%$ of hostesses, who generally work as lead hostesses. They manage to earn a living from it, but usually have other resources at their disposal, such as free housing (SCHÜTZ, 2011). 18. On this point, male greeters are like most men working in "women's" occupations, and differ from women in "men's" occupations, for whom the job is usually the fruit of a carefully nurtured plan (GUICHARD-CLAUDIC et al., 2008). 19. Male greeters are not the only men in "women's" jobs to consider their work temporary. Male cashiers, for example, speak explicitly about leaving their jobs in the medium-term (BERNARD, 2011), while in many other cases, although they 
TABLE 1- Distribution of Women and Men Working as Event Host/ess at Angélique Hôtesses, by Age and Employment Situation at the Time they Applied

\begin{tabular}{lcc}
\hline Age in 2006 & $\begin{array}{c}\text { Event hostesses: women } \\
(N R=0.5 \%, n=245)\end{array}$ & $\begin{array}{c}\text { Event hosts: men } \\
(N R=0 \%, n=134)\end{array}$ \\
\hline Under 20 years old & 8 & 6 \\
$20-24$ & 51 & 39 \\
$25-29$ & 27 & 40 \\
30 and up & 14 & 15 \\
Total & 100 & 100 \\
\hline Situation at time of application & $(N R=11 \%, n=219)$ & $(N R=14 \%, n=115)$ \\
\hline Seeking greeting work & 3 & 0 \\
Seeking work in another sector & 14 & 22 \\
Seeking work to supplement a primary activity & 15 & 23 \\
In school & 68 & 100 \\
Total & 100 & \\
\hline
\end{tabular}

Interpretation: $8 \%$ of women working as event hostesses through Angélique Hôtesses in 2006 were under age 20 at the time of the survey. Field: Random sample of 246 women and 134 men employed by Angélique Hôtesses as event host/ess in 2006. Source: Event host and hostess database (SCHÜTZ, 2011).

TABLE 2- Comparison of Distribution by Educational Qualifications, Women and Men Working as Event Host/ess for Angélique Hôtesses and the French Population Aged 25-34

\begin{tabular}{|c|c|c|c|c|}
\hline \multirow[b]{2}{*}{$\begin{array}{l}\text { Highest } \\
\text { educational degree }\end{array}$} & \multicolumn{2}{|c|}{ Women } & \multicolumn{2}{|c|}{ Men } \\
\hline & $\begin{array}{c}\text { Event hostesses: } \\
\text { women } \\
(N R=9 \% ; n=225)\end{array}$ & $\begin{array}{c}\text { Women } 25-34, \\
\text { general } \\
\text { population }\end{array}$ & $\begin{array}{c}\begin{array}{c}\text { Event hosts: } \\
\text { men }\end{array} \\
(N R=10 \% ; n=121)\end{array}$ & $\begin{array}{c}\text { Man 25-34, } \\
\text { general } \\
\text { population }\end{array}$ \\
\hline Lower than the baccalauréat & 16 & 31.7 & 26 & 45.7 \\
\hline Baccalauréat & 39 & 22.6 & 37 & 19.7 \\
\hline Higher education & 45 & 45.7 & 37 & 34.5 \\
\hline Total & 100 & 100 & 100 & 100 \\
\hline
\end{tabular}

Interpretation: 16\% of women working as event hostesses through Angélique Hôtesses in 2006 had a degree lower than the French baccalauréat (capping high school studies) at the time of the survey, as compared to 31.7\% of women age 25-34 in 2004.

Field: Random sample of 246 women and 134 men employed by Angélique Hôtesses as event host/ess in 2006 Mainland France, individuals aged 25-34.

Source: Event host and hostess database (SCHÜTZ, 2011)/INSEE, Données sociales: la société française - édition 2006, pp. 87-94.

more men are invested in another primary activity (half of them in the arts), thus seeing greeting as secondary. Overall, men in event hosting thus seem less disposed to invest in greeting in the long term, and when they do, it remains a non-essential activity.

In reception work, the very low number of men working through agencies makes it difficult to make statistical comparisons with women. That said, the few male receptionists met over the course of ethnographic research had all found full-time jobs (which is only the case for half of female receptionists), and one of them had even been invited to apply for a supervisor position at the head office, which he ultimately did not 
get. The situation at Entreprendre also points to the existence of a glass escalator for male receptionists; comparison of the stories of Christophe and Bernadette, although they are particular, nonetheless illustrate the mechanisms at work (see Box 2).

\section{Box 2}

\section{A Glass Escalator for the Man and a Dead-End for the Woman}

Christophe ${ }^{1}$ and Bernadette ${ }^{2}$ are both "permanent" receptionists for Entreprendre, which also has two women and one man working on student contracts.

Bernadette is about 50 and has worked at Entreprendre for 30 years. She was first a receptionist after getting her BTS $^{3}$ (roughly the equivalent of an Associates degree) in secretarial work, then worked for a few years in accounting before being sent back to reception in a reorganization of the company. She has been at reception for 25 years now, and is still part-time, at $80 \%$ with two half-days off. This was not her choice, but she ultimately resigned herself to it following the birth of a child 24 years ago and her husband's promotion to department head in local government. Once before having a child and more recently in the past five years, Bernadette has tried to get transferred to positions other than reception so she can develop, but has not succeeded.

Christophe is about 30 and has worked for Entreprendre for five years. After earning a BTS in administrative assistance for small and medium businesses, he started working on a part-time student contract while taking an additional year of course work in economics at the university to earn a licence (roughly the equivalent of a Bachelor's degree), but he ultimately gave up his studies. After three years, he was offered a short-term contract for full-time work, which he accepted for lack of options. Two years later his job was made permanent, on the condition that he take over some of the responsibilities of the handyman, who was retiring. Christophe's responsibilities thus expanded (for example, he sometimes acts as the director's driver) and they take him away from the desk much more often (he only spends $50 \%$ of his time there now). He also takes care of general facilities and office management tasks -maintenance of the company motor pool, managing the food and water bottle stocks, petty building maintenance like changing light bulbs, handling logistics for company-wide meetings, and so on. Since getting a permanent contract, other employees no longer ask him about his occupational aspirations: people think that he has greater responsibilities now, and logically he would also have gotten a raise. His withdrawal from the reception desk has nevertheless left a heavier workload on the remaining staff, who handle just as many calls and administrative tasks as before, but with fewer hands.

Bernadette emphasizes that she has never gotten a raise beyond standard cost-of-living increases, after 30 years of employment at Entreprendre.

1. His parents were labourers who were laid off upon the closure of their factory; the father could not find work, the mother became a housecleaner; interviewed 4 November 2011.

2. Her mother was a housewife and her father an independent businessman, and she was raised by her retired grandmother; interviewed 14 October 2011.

3. A BTS (Brevet de technicien supérieur - Higher-Level Technical Certificate) is a two-year degree pursued in a non-university educational institution following passage of the baccalauréat exam marking the end of secondary-level studies. 
Holding comparable educational qualifications, ${ }^{20}$ these two "permanent" employees of Entreprendre have thus had their careers unfold in extremely different ways, one quickly receiving a full-time job and then a raise, the other resigning herself to part-time work and income stagnation. This comparison shows how strongly gender and job type are connected, making part-time employment a "feminine" work schedule that no one would think of imposing on a man (ANGELOFF, 2000). These cases also allow us to concretely demonstrate the consequences of the differentiation of men's and women's careers described earlier. Christophe's tasks were indeed adjusted to be more "masculine" because all the other employees felt that Christophe did not seem "to be in the right place" at the reception desk. In addition, because Christophe spent less and less time at reception, his tasks were henceforth perceived as being more "technical" and involving greater responsibility, justifying his raise. So not only does Christophe benefit from a (social and financial) promotion that Bernadette has never known, her working conditions deteriorate as a result of his promotion. It thus seems that the glass escalator metaphor is highly applicable to reception work, while proving irrelevant to event hosting, where men have fewer work opportunities and are even less inclined than their female colleagues (who have a slightly different profile) to invest in the long-term career.

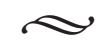

The pioneering work of Christine WILLIAMS (1992) describes the structural advantages benefitting men working in jobs considered to be "feminine" in contrast with the fate reserved for women in the reverse situation. The men she studies do not run up against obstacles in getting hired and, to the contrary, are often very welcome. They are channeled, sometimes against their wishes, toward the job's more valued tasks that allow them to develop - particularly toward administrative tasks with less direct contact with the public. They are included in informal social networks with their hierarchical superiors that speed up their career advancement. These men sometimes actively seek these promotions to counter the stigma of being identified with a "feminine" career, that is often belittled, and poorly paid and to respond to the challenge it poses to their masculinity, a mechanism that works with other factors to pull them upward. Other authors have highlighted the fact that these men are objectively more available for professional activity than their female equivalents, because of the persistent sexual division of domestic and family labour in the private sphere (Le FeUVRE, LAUfER, 2008). Whatever the case, it seems that their choice of an atypical occupation never leads to "feminisation," since a certain number of abilities or skills usually thought of as masculine are assigned exclusively to them, so much so that they occupy a favorable position in the sexual division of labour operating in these occupations (LE FEUVRE, LAUFER, 2008).

20. Note that these are comparable degrees, but not of the same value, given that they were obtained 20 years apart. The contrast between Bernadette and Christophe's career destinies is thus all the more striking, starting from the very beginning of their careers, since far fewer BTS-holders in the 1980s (like Bernadette) were hired as simple administrative employees, more common today given degree inflation. 
Our study builds on these analyses and fully confirms them. It further demonstrates how gendered conceptions of the body, not merely "masculine" and "feminine" skills, also help establish a sexual division of tasks in a "woman's" occupation, assuring men of greater flexibility and freedom. Through an analysis of flirtation, the study reveals the role sexuality plays in organizations in maintaining subordination and a degree of isolation of women at work, while highlighting its virtues for integrating men into masculine social groups that transcend job status. Even though reception staff holds a marginal, even external, position in the division of labour (often spatially manifest in the occupation of the entryway) or divisions by employment type (working through an agency), male receptionists, unlike female receptionists, manage to escape this marginality despite their "minority" position. The power of this mechanism integrating men into an organization is striking, and has been demonstrated in other, non-greeting contexts where sexuality does not enter into the equation. ${ }^{21}$ Ultimately one might even question the very notion of a "minority" position, since men in greeting work, like other men, may indeed be a "minority" in their job but not in their gender position (which serves as a powerful reminder) or in the organizations where they work, where they are in everyday contact with other men with whom they can experience a degree of solidarity.

\section{REFERENCES:}

Angeloff, T. (2000). Le Temps partiel : un marché de dupes ? Paris: Syros.

Angeloff, T., and Arborio, A.-M. (2002). « Des hommes dans des "métiers de femmes": mixité au travail et espaces professionnels dévalorisés. » Sociologia del lavoro, 85, 123-135.

Baudoux, C., and Zaidman, C. (1992). Égalité entre les sexes, mixité et démocratie. Paris: L'Harmattan.

BAUVET, S. (2010). Quelques Économies des relations au travail dans la sécurité privée. Communication au colloque international sur La dimension relationnelle des métiers de service : cache-sexe ou révélateur de genre? (2-3 septembre 2010), université de Lausanne.

BERgER, J. (1972). Ways of Seeing. London: BBC/Harmondsworth: Penguin.

BERnARD, S. (2011). «"C'est pas un homme qui va travailler dans les dentelles !" De l'impossible mixité dans la grande distribution ? » In M. Cacouault-Bitaud, and F. Charles (Eds.), Quelle Mixité dans les formations et les groupes professionnels? Enquêtes sur les frontières et le mélange des genres (pp. 35-55). Paris: L'Harmattan.

21. For instance, Marine CORDIER (2007) shows that female circus performers are more likely to invest in solo performance, while male circus performers are more often part of creative groups where they are authors and directors. These groups advance their careers and exclude women even more effectively because they lead to friendships and voluntary affinities, which are not thought of as a conscious defence against the arrival of women. ForTINO (2002, p. 128) reveals how, in a public company where career advancement occurs primarily through cooptation, men feel like they are part of a group and experience their (frequent) promotions as part of a natural and legitimate course, while women experience their (rare) promotions as accidental favours and unique situations, ungeneralisable and even less exemplary, for which they should be grateful. 
Bessin, M. (2008). « Les hommes dans le travail social : le déni du genre. » In Y. GuichardClaudic, D. Kergoat, and A. Vilbrod (Eds.), L'Inversion du genre. Quand les métiers masculins se conjuguent au féminin... et réciproquement (pp. 357-370). Rennes: Presses universitaires de Rennes.

Bodin, R. (2011). «De la division sexuée des postes dans l'éducation spécialisée. » In M. Cacouault-Bitaud, and F. Charles (Eds.), Quelle Mixité dans les formations et les groupes professionnels? Enquêtes sur les frontières et le mélange des genres (pp. 75-86). Paris: L'Harmattan.

BrochiER, C. (2011). «Le monde social d'une petite usine. » Revue française de sociologie, 52(1), 3-36.

Buscatto, M., and MARry, C. (2009). «Le plafond de verre dans tous ses éclats. La féminisation des professions supérieures au Xx ${ }^{\mathrm{e}}$ siècle. » Sociologie du travail, 51(2), 170-182.

Buscatto, M., and Fusulier, B. (2013). «Les “masculinités” à l'épreuve des métiers "féminins" ", Recherches sociologiques et anthropologiques, 44(2), 1-19.

Cacouault-Bitaud, M., and Charles, F. (Eds.) (2011). Quelle Mixité dans les formations et les groupes professionnels? Enquêtes sur les frontières et le mélange des genres. Paris: L'Harmattan.

Charrier, P. (2004). « Comment envisage-t-on d'être sage-femme quand on est un homme ? » Travail, genre et sociétés, 12, 105-124.

ChArrier, P. (2008). « Des hommes dans une profession “traditionnellement" féminine : choix professionnel et dénomination chez les hommes sages-femmes. » In Y. Guichard-Claudic, D. Kergoat, and A. Vilbrod (Eds.), L'Inversion du genre. Quand les métiers masculins se conjuguent au féminin... et réciproquement (pp. 231-241). Rennes: Presses universitaires de Rennes.

Clair, I. (2012). « Le pédé, la pute et l’ordre hétérosexuel. » Agora, 60, 67-78.

Connell, R. W. (1995). Masculinities. Cambridge: Polity Press.

Connell, R. W., and Messerschmidt, J. W. (2005). "Hegemonic Masculinity: Rethinking the Concept." Gender and Society, 19(6), 829-859.

CORDIER, M. (2007). « Corps en suspens : les genres à l'épreuve dans le cirque contemporain. » Cahiers du genre, 42, 79-100.

CRESSON, G. (2010) « Indicible mais omniprésent : le genre dans les lieux d'accueil de la petite enfance. » Cahiers du genre, 49, 15-33.

CROMER, S., and LEMAIRE, D. (2007). « L'affrontement des sexes en milieu de travail non mixte, observation du système de genre. » Cahiers du genre, 42, 61-78.

Cross, S., and Bagilhole, B. (2002). "Girls' Jobs for the Boys? Men, Masculinity and NonTraditional Occupations.” Gender, Work and Organization, 9(2), 204-226.

Douguet, F., and Vilbrod, A. (2008). « Les infirmiers libéraux : singularité des trajectoires professionnelles et des pratiques de soin. » In Y. Guichard-Claudic, D. Kergoat, and A. Vilbrod 
(Eds.), L'Inversion du genre. Quand les métiers masculins se conjuguent au féminin... et réciproquement (pp. 273-282). Rennes: Presses universitaires de Rennes.

Fortino, S. (1999). « De la ségrégation sexuelle des postes à la mixité au travail : étude d'un processus. » Sociologie du travail, 41(4), 363-384.

ForTino, S. (2002). La Mixité au travail. Paris: La Dispute.

Fraisse, G. (1979). Femmes toutes mains : essai sur le service domestique. Paris: Seuil.

Galbraith, M. (1992). "Understanding Career Choices of Men in Elementary Education.” Journal of Educational Research, 85(4), 246-253.

Gollac, M., and VolKoff, S. (2002). « La mise au travail des stéréotypes de genre : les conditions de travail des ouvrières. » Travail, genre et sociétés, 8, 25-53.

Guichard-Claudic, Y., Kergoat, D., and Vilbrod, A. (Eds.) (2008). L'Inversion du genre. Quand les métiers masculins se conjuguent au féminin... et réciproquement. Rennes: Presses universitaires de Rennes.

GHIGI, R. (2004). « Le corps féminin entre science et culpabilisation. Autour d'une histoire de la cellulite. » Travail, genre et sociétés, 12, 55-75.

Guillaume, C., and Pochic, S. (2007). «La fabrication organisationnelle des dirigeants. Un regard sur le plafond de verre. » Travail, genre et sociétés, 17, 79-101.

Guillaumin, C. (1981). «Femmes et théories de la société : remarques sur les effets théoriques de la colère des opprimées. » Sociologie et société, 2, 19-32.

Guillaumin, C. (1992). Sexe, race et pratique du pouvoir : l'idée de nature. Paris: Côté-Femmes.

Gutek, B. A. (1995). The Dynamics of Service. San Francisco: Jossey-Bass Publishers.

Henson, K. D., Rogers, J. K. (2001). “'Why Marcia You’ve changed!’ Male Clerical Temporary Workers Doing Masculinity in a Feminized Occupation.” Gender and Society, 15(2), 218-238.

HERMAN, E. (2007). « La bonne distance. L'idéologie de la complémentarité légitimée en centre de loisirs. » Cahiers du genre, 42, 121-139.

HidRi NEYS, O. (2013). « Le jeu des apparences : piège ou profit ? Enquête auprès des hôtesses d'accueil et de caisse de la distribution sportive. » Travail et Emploi, 134, 75-89.

JABOIN, Y. (2008). « La construction de l'identité professionnelle masculine dans un secteur en voie de mixité : le cas des hommes enseignant à l'école maternelle. » In Y. Guichard-Claudic, D. Kergoat, and A. Vilbrod (Eds), L'Inversion du genre. Quand les métiers masculins se conjuguent au féminin... et réciproquement (pp. 243-255). Rennes: Presses universitaires de Rennes.

KeRGOAT, D. (1992). «La gestion de la mixité dans un mouvement social : le cas de la coordination infirmière. » In C. Baudoux, and C. Zaidman (Eds.), Égalité entre les sexes, mixité et démocratie (pp. 261-278). Paris; L'Harmattan.

Kergoat, D. (2000). « Division sexuelle du travail et rapports de sexe. » In H. Hirata, F. Laborie, H. Le Doaré, and D. Senotier (Eds.), Dictionnaire critique du féminisme (pp. 35-44). Paris: Presses universitaires de France. 
LADA, E. (2008). « Le genre en pratique et pratiques du genre des hommes dans des emplois de service dits "de femme". » In Y. Guichard-Claudic, D. Kergoat, and A. Vilbrod (Eds.), L'Inversion du genre. Quand les métiers masculins se conjuguent au féminin... et réciproquement (pp. 371-383). Rennes: Presses universitaires de Rennes.

LAUfer, J. (1982). La Féminité neutralisée ? Les femmes cadres dans l'entreprise. Paris: Flammarion.

LAUFER, J. (2005). « La construction du plafond de verre : le cas des femmes cadres à potentiel. » Travail et Emploi, 102, 31-44.

Le Feuvre, N., and Laufer, J. (2008). «Quand l'avancée en mixité est le fait d'hommes. Introduction. » In Y. Guichard-Claudic, D. Kergoat, and A. Vilbrod (Eds.), L'Inversion du genre. Quand les métiers masculins se conjuguent au féminin... et réciproquement (pp. 207-213). Rennes: Presses universitaires de Rennes.

MacKinnon, C. A. (1979). Sexual Harassment of Working Women: A Case of Sex Discrimination. New Haven: Yale University Press.

Molinier, P. (2011). « Le sexuel dans le soin gériatrique. Une "difficulté dans la réalité". » Genre, sexualité \& société, 6. Online http://gss.revues.org/index2193.html (accessed 4 May 2016).

Murcier, N. (2008). «Petite enfance et rapports sociaux de sexe : la formation des professionnel(le)s de la petite enfance, idéologies et représentations sociales. » In Y. GuichardClaudic, D. Kergoat, and A. Vilbrod (Eds.), L'Inversion du genre. Quand les métiers masculins se conjuguent au féminin... et réciproquement (pp. 215-230). Paris: Presses universitaires de Rennes.

Peretz, H. (1992). « Le vendeur, la vendeuse et leur cliente. Ethnographie du prêt-à-porter de luxe. » Revue française de sociologie, 33(1), 49-72.

Perrot, M. (1987). «Qu'est-ce qu'un métier de femme ? » Le Mouvement social, 140, 2-10.

PhILIPPE, C. (2008), « Le conseil conjugal et familial au masculin. » In Y. Guichard-Claudic, D. Kergoat, and A. Vilbrod (Eds.), L'Inversion du genre. Quand les métiers masculins se conjuguent au féminin... et réciproquement (pp. 257-271). Rennes: Presses universitaires de Rennes.

Picot, G. (2011). «Usage du genre et mixité au travail dans les services de soins hospitaliers. » In M. Cacouault-Bitaud, and F. Charles (Eds.), Quelle Mixité dans les formations et les groupes professionnels? Enquêtes sur les frontières et le mélange des genres (pp. 87-101). Paris: L'Harmattan.

Scotт, J. W. (1990). «L'ouvrière, mot impie, sordide. » Actes de la recherche en sciences sociales, $83,2-15$.

Schütz, G. (2006). « Hôtesse d'accueil, les attendus d'un "petit boulot” féminin pour classes moyennes. » Terrains et travaux, 10, 137-156.

SchüTz, G. (2011). Travail et relations hiérarchiques en contexte d'externalisation. Les prestations de services d'hôtesses d'accueil. (Thèse de doctorat en sociologie, Paris, EHESS). 
Sorignet, P.-E. (2004). « La construction des identités sexuées et sexuelles au regard de la socialisation professionnelle : le cas des danseurs contemporains. » Sociologie de l'art, OPuS5, 9-34.

Williams, C. L. (1992). "The Glass Escalator: Hidden Advantages for Men in the 'Female' Professions." Social problems, 39(3), 253-267.

Zolesio, E. (2009). «" "Chirurchiennes" de garde et "humour chirurchical". Posture féminine de surenchère dans l'humour sexuel et scatologique. » Interrogations, 8. Online http://www. revue-interrogations.org/Chirurchiennes-de-garde-et-humour (accessed 4 May 2016). 


\section{APPENDIX}

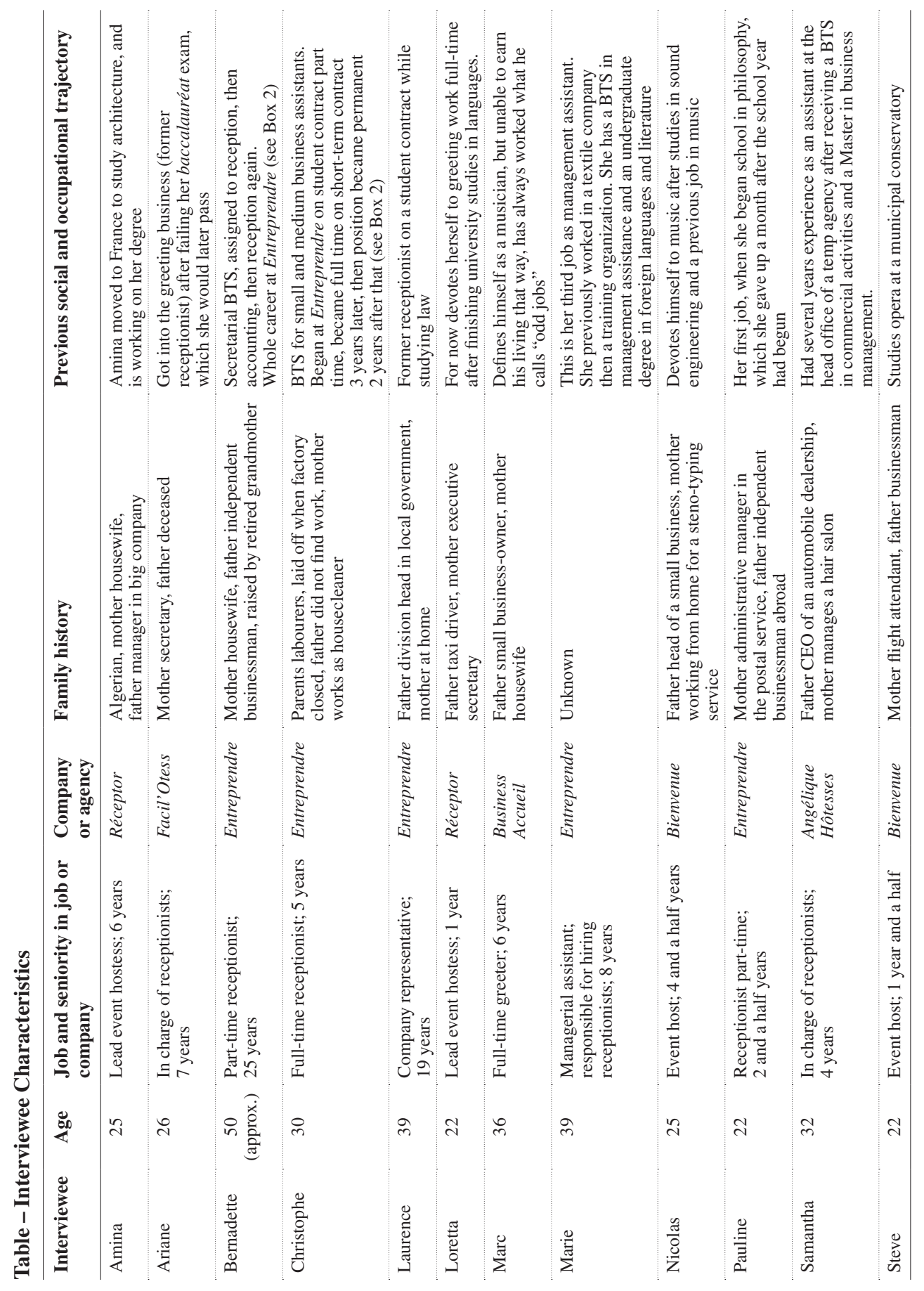

